\title{
The First Example of $\alpha$-Thiomagnesiums Generated from Dithioacetal Monoxides with Grignard Reagent; Their Properties and Some Synthetic Applications
}

\author{
Tsuyoshi SATOH* and Kiyoshi AkitA \\ Department of Chemistry, Faculty of Science, Tokyo University of Science; Kagurazaka, Shinjuku-ku, Tokyo 162-8601, \\ Japan. Received November 5, 2002; accepted December 4, 2002
}

\begin{abstract}
Dithioacetal monoxides were synthesized from aldehydes and cyclohexanone, and reaction of the dithioacetal monoxides with Grignard reagents was investigated. The dithioacetal monoxide synthesized from alkylaldehyde and 4-chlorobenzenethiol reacted with $i$-PrMgCl to afford the desired $\alpha$-thiomagnesium in high yield. The generated $\alpha$-thiomagnesium was found to be stable at room temperature and to be useful in organic synthesis. In contrast to this, the dithioacetal monoxides derived from benzaldehyde and cyclohexanone did not give satisfactory results.
\end{abstract}

Key words $\alpha$-thiomagnesium; dithioacetal monoxide; sulfoxide-magnesium exchange; Grignard reagent

The hydrogen on the carbon bearing an alkylthio or an arylthio group is known to be acidic (for example: $1 ; \mathrm{R}=\mathrm{Ph}$, $\left.\mathrm{R}^{\prime}=\mathrm{H} ; \mathrm{p} K_{\mathrm{a}}=48\right)^{1)}$ and lithium $\alpha$-sulfenyl carbanion 2 can be generated from the sulfide 1 with butyllithium. However, such generation is not an easy task except when $\mathrm{R}^{\prime}$ is a carbanion stabilizing group. For example, Corey and Seebach reported quantitative generation of phenylthiomethyllithium (2: $\left.\mathrm{R}=\mathrm{Ph}, \mathrm{R}^{\prime}=\mathrm{H}\right)$ from thioanisole with $n-\mathrm{BuLi}$ in the presence of Dabco. ${ }^{2)}$ In the absence of Dabco, the yield of the phenylthiomethyllithium was less than $35 \% .{ }^{3,4)}$ Methylthiomethyllithium (2: $\left.\mathrm{R}=\mathrm{CH}_{3}, \mathrm{R}^{\prime}=\mathrm{H}\right)$ was also generated from dimethyl sulfide with $n$-BuLi in the presence of $N, N, N^{\prime}, N^{\prime}$ tetramethylethylenediamine (TMEDA). ${ }^{5)}$ On the other hand, no example of the magnesium $\alpha$-sulfenyl carbanion ( $\alpha$-thio Grignard reagent) has been reported. ${ }^{6-8)}$

Recently, we have extensively studied the generation of alkylmetals having a heteroatom on their $\alpha$-position 4 from sulfoxide $3^{9-18)}$ by the sulfoxide-metal exchange reaction. ${ }^{19}$ In continuation of our interest in the generation of carbanions having a heteroatom on their $\alpha$-position, we investigated the reaction of dithioacetal monoxides 5 with Grignard reagents and we were able to generate, for the first time, $\alpha$-thiomagnesiums 6a. In this paper the generation of the $\alpha$-thiomagnesiums from dithioacetal monoxides and the properties and synthetic application of the generated $\alpha$-thiomagnesiums 6a are described.

\section{Results and Discussion}

Synthesis of Dithioacetal Monoxides from Aldehydes and Cyclohexanone The dithioacetal monoxides used in this study (8-10) were synthesized from 3-phenylpropanal, benzaldehyde, and cyclohexanone, respectively, as shown in Chart 3. For example, 3-phenylpropanal was treated with an equimolar amount of arenethiol in chloroform with $\mathrm{BF}_{3}-\mathrm{OEt}_{2}$ at $0{ }^{\circ} \mathrm{C}$ to give dithioacetal 7 in high yield. Mono-oxidation

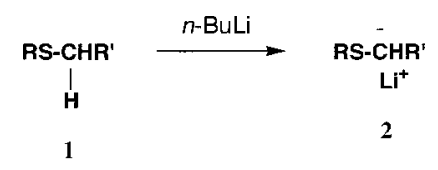

Chart 1 of the dithioacetal was carried out with an equimolar amount of $m$-chloroperbenzoic acid (MCPBA) in a mixture of saturated aqueous $\mathrm{NaHCO}_{3}$ and chloroform at $0{ }^{\circ} \mathrm{C}$ to afford the desired dithioacetal monoxide 8 in over $70 \%$ yield as a mixture of two diastereomers.

The dithioacetal monoxides $\mathbf{8}$ are somewhat unstable under acidic conditions, and the oxidation must be carried out in the presence of a weak base such as $\mathrm{NaHCO}_{3}$. These

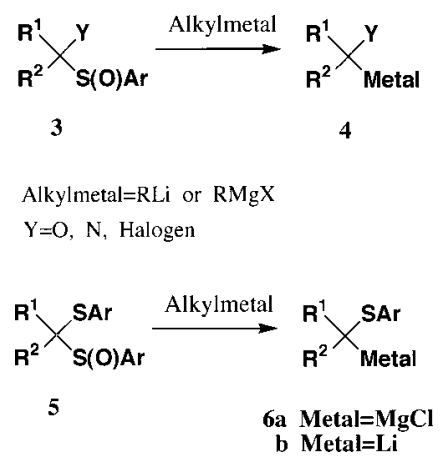

Chart 2
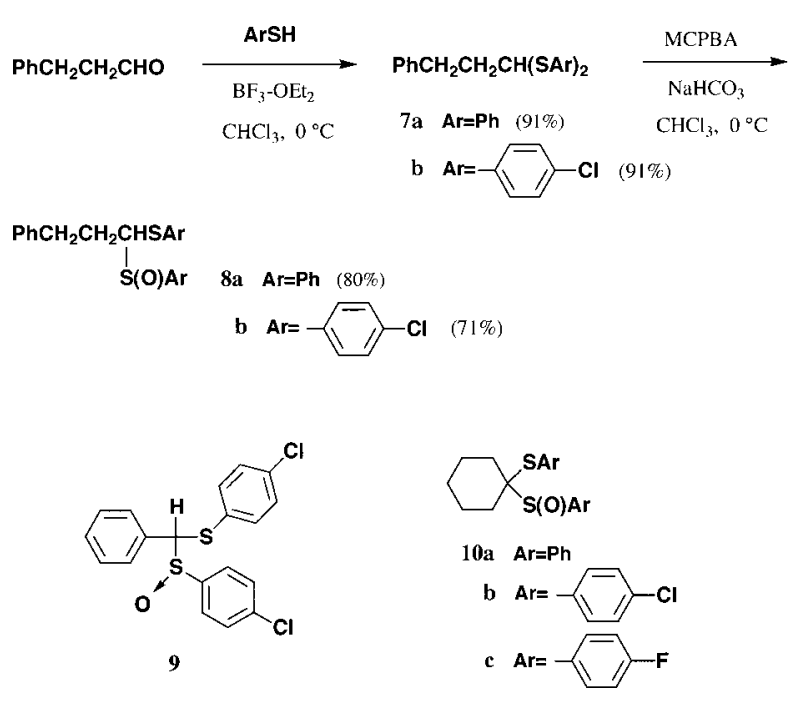

Chart 3 


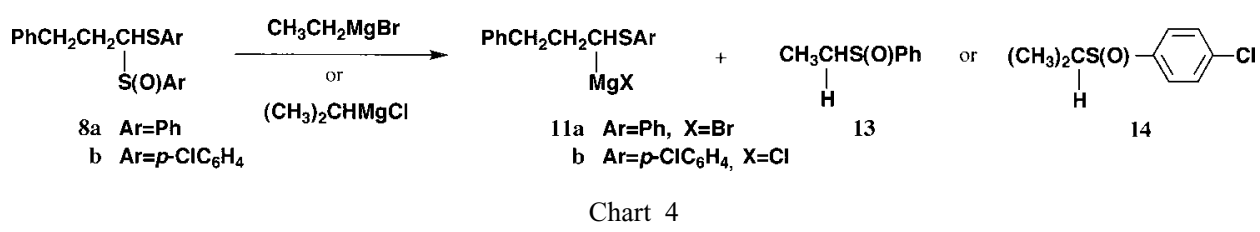

Table 1. Generation of $\alpha$-Thiomagnesiums 11 from $\mathbf{8}$ with Three Equivalents of Grignard Reagent and Trapping with Deuterium Oxide

\begin{tabular}{|c|c|c|c|c|c|}
\hline \multirow{2}{*}{ Entry } & 8 & \multirow{2}{*}{$\mathrm{RMgX}$} & \multirow{2}{*}{ Temp $\left({ }^{\circ} \mathrm{C}\right)$} & \multirow{2}{*}{ Reaction time (min) } & 12 \\
\hline & $\mathrm{Ar}$ & & & & Yield $/ \%(\mathrm{D}$ content $/ \%)$ \\
\hline 1 & $\mathrm{Ph}$ & $\mathrm{EtMgBr}$ & -78 & 15 & 12a $74^{a)}$ \\
\hline 2 & $\mathrm{Ph}$ & $\mathrm{EtMgBr}$ & $-78-$ r.t. & 20 & 12b $87(87)$ \\
\hline 3 & $\mathrm{Ph}$ & EtMgBr & $-78-$ r.t. & 60 & 12b $90(73)$ \\
\hline 4 & $\mathrm{Ph}$ & EtMgBr & $-78-$ r.t. & 360 & 12b $90(57)$ \\
\hline 5 & $p-\mathrm{ClC}_{6} \mathrm{H}_{4}$ & $\mathrm{PhMgBr}$ & r.t. & 30 & $0^{b)}$ \\
\hline 6 & $p-\mathrm{ClC}_{6} \mathrm{H}_{4}$ & $i$-PrMgCl & $-78-$ r.t. & 15 & 12c $85(94)^{c)}$ \\
\hline 7 & $p-\mathrm{ClC}_{6} \mathrm{H}_{4}^{4}$ & $i$-PrMgCl & -78 -r.t. & 60 & 12c $94(89)^{c)}$ \\
\hline 8 & $p-\mathrm{ClC}_{6} \mathrm{H}_{4}$ & $i$-PrMgCl & -78 -r.t. & 360 & $12 \mathrm{c} 90(71)^{c)}$ \\
\hline
\end{tabular}

a) The reaction was quenched with $\mathrm{H}_{2} \mathrm{O}$. b) Starting material and di(4-chlorophenyl) disulfide were obtained. $\quad c$ ) Before the reaction with $i$-PrMgCl, $t$ - $\mathrm{BuMgCl}(0.5$ eq) was added to the reaction mixture in order to remove a trace of moisture in the reaction mixture (see text).

dithioacetal monoxides $\mathbf{8 a}$ and $\mathbf{8 b}$ could be purified by silica gel column chromatography; however, in the case of $\mathbf{8 b}$ recrystallization was found to be more convenient.

Reaction of the Synthesized Dithioacetal Monoxides with Grignard Reagents Reaction of the synthesized dithioacetal monoxides 8-10 with Grignard reagents was investigated. First, dithioacetal monoxide $\mathbf{8 a}$ was added dropwise to a solution of $\mathrm{EtMgBr}(3 \mathrm{eq})$ in $\mathrm{THF}$ at $-78^{\circ} \mathrm{C}$ and after $15 \mathrm{~min}$, the reaction was quenched with water (Chart 4 and Table 1, entry 1). The starting material 8a disappeared and the desired phenyl 3-phenylpropyl sulfide 12a was isolated in $74 \%$ yield. This result indicates that the desired sulfoxide-magnesium exchange takes place and $\alpha$-thiomagnesium 11a must be formed.

Next, this reaction was conducted at $-78^{\circ} \mathrm{C}$ and after the addition of $\mathbf{8 a}$, the cooling bath was removed and the reaction mixture was stirred at room temperature and finally the reaction was quenched with deuterium oxide (entries 2-4). As shown in entries $2-4$, yield of the isolated deuterated sulfide 12b was about 90\%; however, deuterium incorporation was not satisfactory ( $87 \%$ ) even right after the sulfoxidemetal exchange reaction was carried out (entry 2) and was slowly decreased from $87 \%$ to $57 \%$ after $6 \mathrm{~h}$ at room temperature. One reason why this problem arises was supposed to be the trace moisture in the reaction medium. Another reason was supposed to be the generated ethyl phenyl sulfoxide $\mathbf{1 3}$ (see Chart 4) which has a rather acidic hydrogen on the carbon bearing the sulfinyl group.

In view of these results, we came up with some modification of the reaction conditions. First, we synthesized a dithioacetal monoxide having an electron-withdrawing group on the aromatic ring. The selected aromatic ring was $p$ chlorophenyl group $\mathbf{8 b}$. We anticipated that the carbanion of 11b is stabilized and the basicity of $\mathbf{1 1 b}$ could be lowered by the electron-withdrawing nature of the chlorine atom. Sec- ond, we investigated other Grignard reagents such as $\mathrm{Ph}-$ $\mathrm{MgBr}$ and $i$-PrMgCl. Third, before the sulfoxide-magnesium exchange reaction, $t$ - $\mathrm{BuMgCl}(0.5 \mathrm{eq})$ was added to the reaction mixture to remove the trace of moisture in the reaction medium. Note that $t-\mathrm{BuMgCl}$ has been found to be inert to the sulfoxides.

To overcome the above-mentioned problem, first of all, we investigated the reaction of $\mathbf{8 b}$ with $\mathrm{PhMgBr}$, because we thought that if the reaction worked, the produced by-product, $p$-chlorophenyl phenyl sulfoxide, would have no acidic hydrogen. However, the sulfoxide-magnesium exchange reaction did not take place even at room temperature (entry 5).

Next, $8 \mathbf{b}$ was treated with $t-\mathrm{BuMgCl}(0.5 \mathrm{eq})$ followed by $i$-PrMgCl at $-78^{\circ} \mathrm{C}$, then at room temperature for $15 \mathrm{~min}$ (entry 6). The reaction worked quite good to give a high yield of the sulfide 12c with high deuterium content (94\%). The generated $\alpha$-thiomagnesium $\mathbf{1 1 b}$ was found to be stable at room temperature within $1 \mathrm{~h}$ (entry 7$)$. However, 11b was slowly protonated at room temperature (entry 8). As mentioned above, the proton source of this reaction was thought to be the generated sulfoxide $\mathbf{1 4}$. We separated the sulfoxide from the reaction mixture and investigated by ${ }^{1} \mathrm{H}-\mathrm{NMR}$ if the deuterium incorporation took place and we found that no deuterium was incorporated in the sulfoxide 14. In any event, we found that the $\alpha$-thiomagnesium 11b could be generated and it could be used at room temperature for at least $1 \mathrm{~h}$.

Before the study to apply the generated $\alpha$-thiomagnesium 11b in organic synthesis, we investigated the sulfoxide-magnesium exchange reaction with the dithioacetal monoxide derived from benzaldehyde and cyclohexanone, 9 and $\mathbf{1 0}$, respectively.

The results for the sulfoxide-nagnesium exchange reaction of 9 with Grignard reagents are summarized in Chart 5. The sulfoxide 9 was treated with EtMgBr, $i$-PrMgCl, and $\mathrm{Ph}-$ $\mathrm{MgBr}$. The sulfoxide-magnesium exchange reaction took 
place even with $\mathrm{PhMgBr}$ at $-78^{\circ} \mathrm{C}$; however, these reactions were not always completed and a considerable amount of the starting material 9 remained in the reaction mixture even with a large excess amount of the Grignard reagent added. The yield of sulfide $\mathbf{1 5}$ was less than $67 \%$.

When this reaction was quenched with $\mathrm{D}_{2} \mathrm{O}$, we found that the remained starting material was not 9 but deuterated sulfoxide 16 (deuterium incorporation was over 99\%). These results implied that when the reaction of 9 with the Grignard reagent was carried out, both the sulfoxide-magnesium exchange reaction (gave 17) and hydrogen abstraction (gave 18) took place competitively, because the hydrogen on the carbon bearing the sulfoxide is highly acidic.

The results for the reaction of dithioacetal monoxide $\mathbf{1 0}$ with Grignard reagents are summarized in Table 2. The sulfoxide 10a did not react at all with $\mathrm{EtMgBr}$ at room temperature (entry 1). Quite interestingly, the reaction took place in the presence of HMPA to give 19a; however, the deuterium content was very low (entry 2). The sulfoxide-magnesium exchange reaction of $\mathbf{1 0 b}$ proceeded with $\mathrm{EtMgBr}$ without

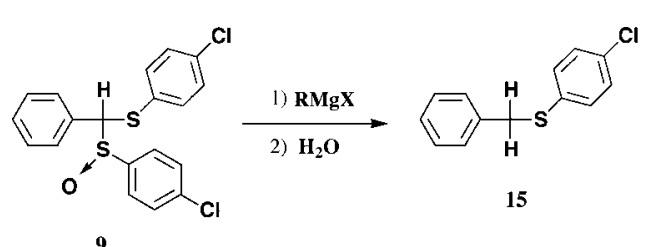

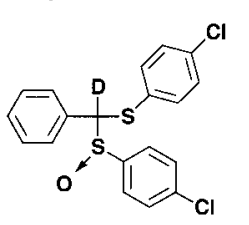

16

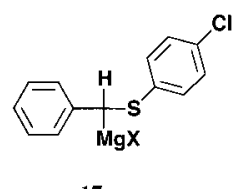

17

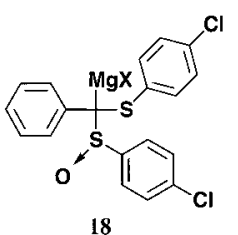

Chart 5
HMPA to afford 19b and the deuterium incorporation was $60 \%$ (entry 3 ). In the presence of HMPA, the deuterium content was found to be $0 \%$ (entry 4 ). This reaction took place with $i$-PrMgCl with slightly better results; however, the deuterium content was still less than $60 \%$ (entry 5).

Entries 6 and 7 show the results with 10c. As shown in Table 2 , the deuterium content was found to be slightly better, but the chemical yield of 19c could not be improved. The sulfoxide-magnesium exchange reaction of $\mathbf{9}$ and $\mathbf{1 0}$, on the whole, was found to be unsuccessful for the generation of $\alpha$ thiomagnesums in significant yield.

An Application of the Generated $\alpha$-Thiomagnesium 11b in Organic Synthesis Next, we investigated the reactivity of the $\alpha$-thiomagnesium $\mathbf{1 1 b}$ derived from $\mathbf{8 b}$ by the sulfoxide-magnesium exchange reaction with some electrophiles (Chart 6, Table 3). In a solution of $\mathbf{1 1 b}$, generated from $\mathbf{8 b}$ under the conditions shown in Table 1 (entry 6), 5 equivalents of ethyl chloroformate was added and the reaction mixture was stirred at room temperature for $30 \mathrm{~min}$ to give the ester 20 in 51\% yield (Chart 6). Reductive desulfurization of the $p$-chlorophenylthio group was easily carried out with $\mathrm{Bu}_{3} \mathrm{SnH}$ to afford ethyl 4-phenylbutyrate $\mathbf{2 1}$ in almost quantitative yield. ${ }^{20-24)}$ Oxidation of the sulfur in 20 with MCPBA followed by thermal elimination of the resulting sulfoxide afforded the $\alpha, \beta$-unsaturated ester 22 in $84 \%$ overall yield.

Reactions of the $\alpha$-thiomagnesium 11b with several electrophiles other than ethyl chloroformate are summarized in Table 3. As shown in Table 3, the $\alpha$-thiomagnesium 11b was found to have relatively low reactivity compared to that of other simple Grignard reagents. Alkylation of 11b with several halogenoalkanes gave the alkylated products $\mathbf{2 3 - 2 6}$ in low to moderate yields (entry 1-4). Excellent yield was obtained with benzaldehyde (entry 5); however, 11b did not add to 3-phenylpropanal. Addition of 11b to 2,2-dimethylpropanal gave the adduct $\mathbf{2 8}$ in only $26 \%$ yield (entry 6 ). Benzoyl chloride and phenyl isocyanate reacted to give the desired products $\mathbf{2 9}$ and $\mathbf{3 0}$; however, the yields were only up to $34 \%$.

In conclusion, we were able to generate, for the first time, $\alpha$-thiomagnesiums from dithioacetal monoxides by the sulfoxide-magnesium exchange reaction. The generated $\alpha$ thiomagensiums were found to be stable at room temperature; however, the reactivity toward several electrophiles was

Table 2. Reaction of the Dithioacetal Monoxide 10 with Grignard Reagent

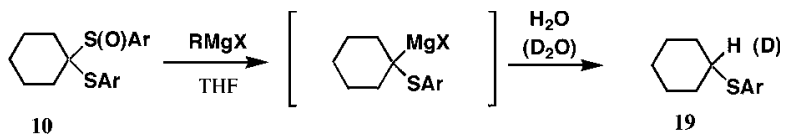

10

19

\begin{tabular}{|c|c|c|c|c|c|}
\hline \multirow{2}{*}{ Entry } & \multirow{2}{*}{$\mathrm{Ar}$} & \multirow{2}{*}{$\mathrm{RMgX}$} & \multirow{2}{*}{ Temp $\left({ }^{\circ} \mathrm{C}\right)$} & \multirow{2}{*}{ Reaction time (min) } & 19 \\
\hline & & & & & Yield $/ \%(\mathrm{D} \text { content } / \%)^{a)}$ \\
\hline 1 & $\mathrm{Ph}$ & EtMgBr & r.t. & 60 & $0^{b)}$ \\
\hline 2 & $\mathrm{Ph}$ & $\mathrm{EtMgBr}^{c)}$ & r.t. & 30 & 19a $65(9)$ \\
\hline 3 & $p-\mathrm{ClC}_{6} \mathrm{H}_{4}$ & EtMgBr & r.t. & 8 & 19b $90(60)$ \\
\hline 4 & $p-\mathrm{ClC}_{6} \mathrm{H}_{4}$ & $\mathrm{EtMgBr}^{c)}$ & r.t. & 8 & 19b $93(0)$ \\
\hline 5 & $p-\mathrm{ClC}_{6} \mathrm{H}_{4}$ & $i-\mathrm{PrMgCl}$ & 0 -r.t. & 8 & 19b $96(58)$ \\
\hline 6 & $p-\mathrm{ClC}_{6} \mathrm{H}_{4}$ & EtMgBr & 0 -r.t. & 8 & 19c 74 \\
\hline 7 & $p-\mathrm{ClC}_{6} \mathrm{H}_{4}$ & $i$-PrMgCl & r.t. & 6 & 19c $74(63)$ \\
\hline
\end{tabular}

a) Deuterium incorrporation was measured by ${ }^{1} \mathrm{H}-\mathrm{NMR}$. b) No reaction. c) The reaction was carried out in the presence of HMPA. 


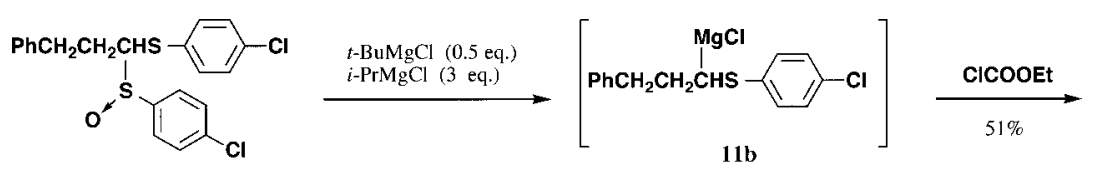

$8 \mathrm{~b}$

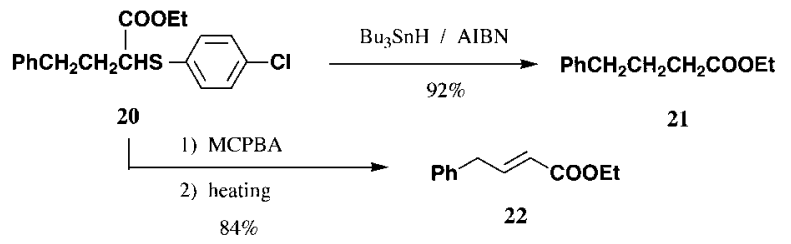

Chart 6

Table 3. Reaction of the Generated $\alpha$-Thomagnesium 11b with Electrophiles

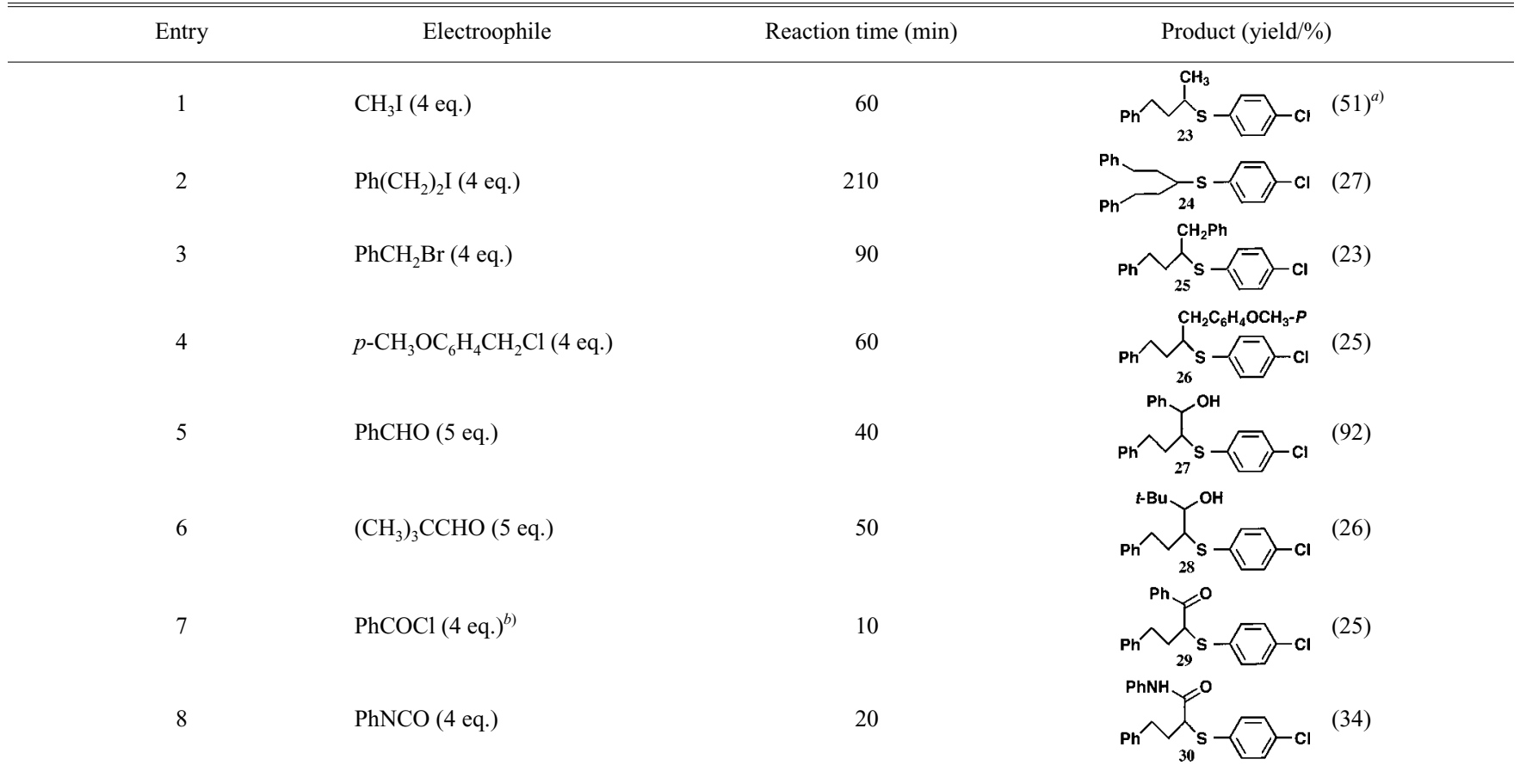

a) The product of this reaction was a mixture of $\mathbf{2 3}(51 \%)$ and 12a $(25 \%)$. The yield was calculated by ${ }^{1} \mathrm{H}-\mathrm{NMR}$. b) The reaction was carried out at $-78{ }^{\circ} \mathrm{C}$.

found to be low.

\section{Experimental}

Melting points were measured with a Yanagimoto micro melting point apparatus and are uncorrected. ${ }^{1} \mathrm{H}-\mathrm{NMR}$ spectra were measured in a $\mathrm{CDCl}_{3}$ solution with JEOL JNM-LA 400 and 500 spectrometer. Electron-impact mass spectra (MS) were obtained at $70 \mathrm{eV}$ by direct insertion. Silica gel 60 (MERCK) containing $0.5 \%$ fluorescence reagent 254 and a quartz column were used for column chromatography and the products having UV absorption were detected by UV irradiation. In experiments requiring a dry solvent, THF was distilled from benzophenone ketyl; HMPA and diisopropylamine were distilled from $\mathrm{CaH}_{2}$. The molecular sieves 4A used in this study was flame-dried under Ar atmosphere before use.

1,1-Bis(phenylthio)-3-phenylpropane (7a) To a solution of 3-phenylpropanal $(4.27 \mathrm{~g}, 32.6 \mathrm{mmol})$ and benzenethiol $(7.4 \mathrm{ml}, 71.7 \mathrm{mmol})$ in $40 \mathrm{ml}$ of $\mathrm{CHCl}_{3}$ at $0{ }^{\circ} \mathrm{C}$ was added dropwise $\mathrm{BF}_{3}-\mathrm{Et}_{2} \mathrm{O}(9.9 \mathrm{ml}, 78.9 \mathrm{mmol})$. The reaction mixture was stirred at $0{ }^{\circ} \mathrm{C}$ for $1 \mathrm{~h}$. The reaction was quenched by sat. aq. $\mathrm{NaHCO}_{3}$ and the whole was extracted with $n$-hexane. The organic solution was washed with $5 \% \mathrm{NaOH}$ followed by water. The solution was dried over anhydrous $\mathrm{MgSO}_{4}$ and the solvent was evaporated. The product was purified by silica gel column chromatography to give $7 \mathbf{a}(9.99 \mathrm{~g}, 91 \%)$ as colorless oil. IR (neat) $3059,2921,1582,1479,1438,1024,739,691 \mathrm{~cm}^{-1} ;{ }^{1} \mathrm{H}-$ NMR $\delta 2.14(2 \mathrm{H}, \mathrm{q}, J=7.3 \mathrm{~Hz}), 2.92(2 \mathrm{H}, \mathrm{t}, J=7.5 \mathrm{~Hz}), 4.35(1 \mathrm{H}, \mathrm{t}, J=6.7$ $\mathrm{Hz}), 7.11(2 \mathrm{H}, \mathrm{d}, J=8.0 \mathrm{~Hz}), 7.17-7.20(1 \mathrm{H}, \mathrm{m}), 7.24-7.30(8 \mathrm{H}, \mathrm{m})$,
7.39-7.41 (4H, m). MS m/z (\%) $336\left(\mathrm{M}^{+}, 10\right), 227$ (22), 149 (7), 117 (100), 91 (83). Calcd for $\mathrm{C}_{21} \mathrm{H}_{20} \mathrm{~S}_{2}: \mathrm{M}, 336.1007$. Found: $m / z 336.1009$.

1,1-Bis( $p$-chlorophenylthio)-3-phenylpropane (7b): Colorless oil. IR (neat) 3025, 2923, 1475, 1093, 1013, 821, 746, $700 \mathrm{~cm}^{-1}$; ${ }^{1} \mathrm{H}-\mathrm{NMR} \delta 2.10$ $(2 \mathrm{H}, \mathrm{q}, J=7.2 \mathrm{~Hz}), 2.90(2 \mathrm{H}, \mathrm{t}, J=7.5 \mathrm{~Hz}), 4.24(1 \mathrm{H}, \mathrm{t}, J=6.9 \mathrm{~Hz}), 7.11-$ $7.14(2 \mathrm{H}, \mathrm{m}), 7.19-7.31(11 \mathrm{H}, \mathrm{m}) . \mathrm{MS} m / z(\%) 404\left(\mathrm{M}^{+}, 5\right), 261(14), 149$ (13), 117 (100), 91 (78). Calcd for $\mathrm{C}_{21} \mathrm{H}_{18} \mathrm{Cl}_{2} \mathrm{~S}_{2}$ : M, 404.0226. Found: $m / z$ 404.0219 .

1-(Phenylsulfinyl)-1-(phenylthio)-3-phenylpropane (8a) To a suspension of dithioacetal 7a $(1.94 \mathrm{~g}, 5.7 \mathrm{mmol})$ in sat. aq. $\mathrm{NaHCO}_{3}(23 \mathrm{ml})$ and $\mathrm{CHCl}_{3}(11.4 \mathrm{ml})$ at $0{ }^{\circ} \mathrm{C}$ was added MCPBA $(1.48 \mathrm{~g}, 5.99 \mathrm{mmol})$ with stirring. The reaction mixture was stirred for $30 \mathrm{~min}$. The reaction was quenched with sat. aq. $\mathrm{Na}_{2} \mathrm{SO}_{3}$ and the whole was extracted with $n$-hexane and AcOEt. The organic solution was washed with water and dried over anhydrous $\mathrm{MgSO}_{4}$. The solvent was evaporated and the residue was purified by silica gel column chromatography to give 8a (diastereomeric mixture) (1.62 g, $80 \%$ ) as colorless viscous oil. IR (neat) 3060, 1476, 1442, 1086, 1047 (SO), $748,691 \mathrm{~cm}^{-1}$; ${ }^{1} \mathrm{H}-\mathrm{NMR} \delta 1.34-1.42(0.4 \mathrm{H}, \mathrm{m}), 1.92-2.00(0.6 \mathrm{H}, \mathrm{m})$, $2.38-2.45(0.6 \mathrm{H}, \mathrm{m}), 2.49-2.56(0.4 \mathrm{H}, \mathrm{m}), 2.74-2.83(1 \mathrm{H}, \mathrm{m}), 3.00-$ $3.07(1 \mathrm{H}, \mathrm{m}), 3.81(0.6 \mathrm{H}, \mathrm{dd}, J=10.7,3.1 \mathrm{~Hz}), 4.07(0.4 \mathrm{H}, \mathrm{dd}, J=11.0$, $3.4 \mathrm{~Hz}), 7.03-7.75(15 \mathrm{H}, \mathrm{m})$; MS $m / z(\%) 353\left([\mathrm{M}+\mathrm{H}]^{+}\right.$, trace), $352\left(\mathrm{M}^{+}\right.$, trace), 226 (41), 117 (100), 91 (44). Calcd for $\mathrm{C}_{21} \mathrm{H}_{21} \mathrm{OS}_{2}$ : [M+H], 353.1034. Found: $m / z$ 353.1014.

1-( $p$-Chlorophenylsulfinyl)-1-( $p$-chlorophenylthio)-3-phenylpropane (8b): 
Colorless crystals (diastereomeric mixture). mp $76.8-77.5^{\circ} \mathrm{C}$ (AcOEthexane); IR (KBr) 3026, 2923, 1475, 1093, 1050 (SO), 1012, 820, 743, $700 \mathrm{~cm}^{-1} ;{ }^{1} \mathrm{H}-\mathrm{NMR} \delta 1.36-1.59(0.4 \mathrm{H}, \mathrm{m}), 1.85-1.95(0.6 \mathrm{H}, \mathrm{m}), 2.33-$ $2.42(0.6 \mathrm{H}, \mathrm{m}), 2.45-2.54(0.4 \mathrm{H}, \mathrm{m}), 2.75-2.85(1 \mathrm{H}, \mathrm{m}), 3.00-3.08(1 \mathrm{H}$, $\mathrm{m}), 3.75(0.6 \mathrm{H}, \mathrm{dd}, J=13.9,3.8 \mathrm{~Hz}), 3.98(0.4 \mathrm{H}, \mathrm{dd}, J=13.7,4.3 \mathrm{~Hz}), 7.05-$ 7.64 (13H, m). MS m/z (\%) 260 (39), 160 (17), 143 (12), 117 (100), 91 (23). Anal. Calcd: C, 59.85; H, 4.31; Cl, 16.83; S, 15.22. Found: C, 59.54; H, $4.81 ; \mathrm{Cl}, 16.59 ; \mathrm{S}, 15.21$.

( $p$-Chlorophenylsulfinyl)( $p$-chlorophenylthio)phenylmethane (9): Colorless crystals (diastereomeric mixture). mp $130.5-132.0^{\circ} \mathrm{C}$ (benzene); IR (KBr) 1482, 1095, $1050(\mathrm{SO}), 1010,818,698 \mathrm{~cm}^{-1} ;{ }^{1} \mathrm{H}-\mathrm{NMR} \delta 4.96(0.3 \mathrm{H}$, s), $5.01(0.7 \mathrm{H}, \mathrm{s}), 7.04-7.53(13 \mathrm{H}, \mathrm{m}) . \mathrm{MS} m / z$ (\%) 286 (94), 233 (6), 143 (100), 108 (49).

1-(Phenylsulfinyl)-1-(phenylthio)cyclohexane (10a): Colorless crystals. mp 105-106 ${ }^{\circ} \mathrm{C}$ (AcOEt); IR (KBr) 2931, 1439, 1079, 1046 (SO), 748, $686 \mathrm{~cm}^{-1}$; ${ }^{1} \mathrm{H}-\mathrm{NMR} \delta 0.96-0.99(1 \mathrm{H}, \mathrm{m}), 1.15-1.24(1 \mathrm{H}, \mathrm{m}), 1.53-1.78$ $(6 \mathrm{H}, \mathrm{m}), 1.89-1.95(1 \mathrm{H}, \mathrm{m}), 2.04-2.10(1 \mathrm{H}, \mathrm{m}), 7.35-7.42(3 \mathrm{H}, \mathrm{m})$, $7.48-7.54(3 \mathrm{H}, \mathrm{m}), 7.72-7.74(2 \mathrm{H}, \mathrm{m}), 7.91-7.93(2 \mathrm{H}, \mathrm{m}) . \mathrm{MS} m / z(\%)$ 218 (100), 185 (7), 154 (10), 140 (3), 109 (66).

1-( $p$-Chlorophenylsulfinyl)-1-( $p$-chlorophenylthio)cyclohexane $\quad(\mathbf{1 0 b})$ : Colorless crystals. mp $105-106^{\circ} \mathrm{C}(\mathrm{AcOEt})$; IR (KBr) 2935, 1476, 1093, 1040 (SO), 1012, $816 \mathrm{~cm}^{-1}$; ${ }^{1} \mathrm{H}-\mathrm{NMR} \delta 0.99-1.01(1 \mathrm{H}, \mathrm{m}), 1.15-1.25$ $(1 \mathrm{H}, \mathrm{m}), 1.55-1.73(6 \mathrm{H}, \mathrm{m}), 1.84-1.90(1 \mathrm{H}, \mathrm{m}), 2.00-2.06(1 \mathrm{H}, \mathrm{m})$, $7.34-7.36(2 \mathrm{H}, \mathrm{m}), 7.47-7.50(2 \mathrm{H}, \mathrm{m}), 7.65-7.68(2 \mathrm{H}, \mathrm{m}), 7.81-7.84$ (2H, m). MS m/z (\%) 286 (13), 224 (98), 160 (36), 143 (34), 112 (46), 108 (37), 81 (100). Anal. Calcd: C, 56.10; H, 4.71; Cl, 18.40; S, 16.64. Found: C, 55.89; H, 4.55; Cl, 18.44; S, 16.79 .

1-(p-Fluorophenylsulfinyl)-1-(p-fluorophenylthio)cyclohexane (10c): Colorless crystals. mp $108-109^{\circ} \mathrm{C}$ (AcOEt); IR (KBr) 2931, 1489, 1235, 1047 (SO), $835 \mathrm{~cm}^{-1}$; ${ }^{1} \mathrm{H}-\mathrm{NMR} \delta 0.96-0.99(1 \mathrm{H}, \mathrm{m}), 1.15-1.26(1 \mathrm{H}, \mathrm{m})$, $1.54-1.76(6 \mathrm{H}, \mathrm{m}), 1.83-1.91(1 \mathrm{H}, \mathrm{m}), 2.00-2.07(1 \mathrm{H}, \mathrm{m}), 7.04-7.10$ $(2 \mathrm{H}, \mathrm{m}), 7.18-7.24(2 \mathrm{H}, \mathrm{m}), 7.69-7.74(2 \mathrm{H}, \mathrm{m}), 7.87-7.92(2 \mathrm{H}, \mathrm{m}) . \mathrm{MS}$ $\mathrm{m} / \mathrm{z}(\%) 254$ (95), 208 (27), 127 (100), 83 (41), 81 (22).

1-(Phenylthio)-3-phenylpropane (12a) To a solution of EtMgBr $(0.6 \mathrm{ml}, 0.6 \mathrm{mmol})$ in $2 \mathrm{ml}$ of THF at $-78^{\circ} \mathrm{C}$ was added dropwise with stirring a solution of dithioacetal monoxide $8 \mathbf{a}(70.5 \mathrm{mg}, 0.2 \mathrm{mmol})$ in THF. The reaction mixture was stirred for $15 \mathrm{~min}$. The reaction was quenched by sat. aq. $\mathrm{NH}_{4} \mathrm{Cl}$ and the whole was extracted with $n$-hexane. The solution was dried over anhydrous $\mathrm{MgSO}_{4}$ and the solvent was evaporated. The product was purified by silica gel column chromatography to give 12a $(40.2 \mathrm{mg}$, $87 \%$ ) as colorless oil. IR (neat) 2916, 1583, 1480, 1438, 1091, 1025, 737, $690 \mathrm{~cm}^{-1}$; ${ }^{1} \mathrm{H}-\mathrm{NMR} \delta 1.97(2 \mathrm{H}$, quin, $J=7.4 \mathrm{~Hz}), 2.75(2 \mathrm{H}, \mathrm{t}, J=7.5 \mathrm{~Hz})$, $2.92(2 \mathrm{H}, \mathrm{t}, J=7.2 \mathrm{~Hz}), 7.14-7.20(4 \mathrm{H}, \mathrm{m}), 7.25-7.31(6 \mathrm{H}, \mathrm{m}) . \mathrm{MS} \mathrm{m} / \mathrm{z}$ (\%) $228\left(\mathrm{M}^{+}, 92\right), 137$ (14), 118 (100), $110(37), 91$ (63), 77 (17). Calcd for $\mathrm{C}_{15} \mathrm{H}_{16} \mathrm{~S}: \mathrm{M}, 228.0971$. Found: $m / z 228.0967$.

1-Deuterio-1-(phenylthio)-3-phenylpropane (12b) Above-mentioned reaction was quenched with $\mathrm{D}_{2} \mathrm{O}$. The product was purified by silica gel column chromatography to give 12b (87\%). MS $m / z(\%) 229\left(\mathrm{M}^{+}, 90\right), 138$ (14), 119 (100), 110 (45), 91 (62), 77 (15). Calcd for $\mathrm{C}_{15} \mathrm{H}_{15} \mathrm{DS}: \mathrm{M}$, 229.1034. Found: $m / z 229.1043$.

1-Deuterio-1-(p-chlorophenylthio)-3-phenylpropane (12c) To a solution of $t-\mathrm{BuMgCl}(0.1 \mathrm{ml}, 0.1 \mathrm{mmol})$ in $2 \mathrm{ml}$ of THF at $-78^{\circ} \mathrm{C}$ was added dropwise with stirring a solution of dithioacetal monoxide $\mathbf{8 b}(84.2 \mathrm{mg}$, $0.2 \mathrm{mmol}$ ) in THF. After $5 \mathrm{~min}$, to the reaction mixture was added dropwise $i-\mathrm{PrMgCl}(0.3 \mathrm{ml}, 0.6 \mathrm{mmol})$ and warmed to room temperature. After $15 \mathrm{~min}$, the reaction was quenched by $\mathrm{D}_{2} \mathrm{O}$ and the whole was extracted with $n$-hexane. The solution was dried over anhydrous $\mathrm{MgSO}_{4}$ and the solvent was evaporated. The product was purified by silica gel column chromatography to give 12c $(40.2 \mathrm{mg}, 87 \%)$. Protonation $(\mathrm{H})$ product: colorless oil. IR (neat) $3025,2933,1476,1096,1011,811,746,699 \mathrm{~cm}^{-1}$; ${ }^{1} \mathrm{H}-\mathrm{NMR} \delta 1.95$ $(2 \mathrm{H}$, quin, $J=7.4 \mathrm{~Hz}), 2.74(2 \mathrm{H}, \mathrm{t}, J=7.5 \mathrm{~Hz}), 2.89(2 \mathrm{H}, \mathrm{t}, J=7.3 \mathrm{~Hz})$, $7.12-7.31(8 \mathrm{H}, \mathrm{m}) .{ }^{13} \mathrm{C}-\mathrm{NMR} \delta 30.46,33.03,34.57,126.03,128.41$, $128.45,128.99,130.38,131.74,135.05,141.07$. MS $m / z(\%) 262\left(\mathrm{M}^{+}, 68\right)$, 171 (8), 144 (29), 118 (100), 108 (15), 91 (75), 77 (8). Calcd for $\mathrm{C}_{15} \mathrm{H}_{15} \mathrm{ClS}$ : M, 262.0582. Found: $\mathrm{m} / \mathrm{z}$ 262.0583. Deuteration (D) product: MS $\mathrm{m} / \mathrm{z}(\%)$ $263\left(\mathrm{M}^{+}, 62\right), 172$ (7), 144 (33), 119 (100), 108 (16), 91 (72), 77 (8). Calcd for $\mathrm{C}_{15} \mathrm{H}_{14} \mathrm{DClS}$ : M, 263.0645. Found: $m / z 263.0652$.

(p-Chlorophenylthio)phenylmethane (15) To a solution of EtMgCl $(0.5 \mathrm{ml}, 0.5 \mathrm{mmol})$ in $1.6 \mathrm{ml}$ of THF at $-40^{\circ} \mathrm{C}$ was added dropwise with stirring a solution of dithioacetal monoxide $9(39.3 \mathrm{mg}, 0.1 \mathrm{mmol})$ in THF. The reaction mixture was allowed to warm to room temperature and stirred for $2 \mathrm{~h}$. The reaction was quenched by sat. aq. $\mathrm{NH}_{4} \mathrm{Cl}$ and the whole was extracted with $n$-hexane. The solution was dried over anhydrous $\mathrm{MgSO}_{4}$ and the solvent was evaporated. The product was purified by silica gel column chromatography to give $\mathbf{1 5}(15.7 \mathrm{mg}, 67 \%)$ as a low-melting solid. IR (KBr) $1477,1100,813,712,695 \mathrm{~cm}^{-1} ;{ }^{1} \mathrm{H}-\mathrm{NMR}$ (solvent $\left.\mathrm{CDCl}_{3}\right) \delta 4.08(2 \mathrm{H}, \mathrm{s})$, $7.21(4 \mathrm{H}, \mathrm{s}), 7.23-7.31(5 \mathrm{H}, \mathrm{m}),{ }^{1} \mathrm{H}-\mathrm{NMR}$ (solvent $\left.\mathrm{CD}_{3} \mathrm{OD}\right) \delta 4.12(2 \mathrm{H}, \mathrm{s})$, 7.17-7.28 (9H, m). MS m/z (\%) $234\left(\mathrm{M}^{+}, 25\right), 143$ (5), 108 (6), 91 (100). Calcd for $\mathrm{C}_{13} \mathrm{H}_{11} \mathrm{ClS}: \mathrm{M}, 234.0269$. Found: $m / z 234.0279$.

Phenylthiocyclohexane (19a) To a solution of $\mathrm{EtMgBr}(0.6 \mathrm{ml}$, $0.6 \mathrm{mmol})$ and HMPA $(0.32 \mathrm{ml}, 1.8 \mathrm{mmol})$ in $2 \mathrm{ml}$ of THF at room temperature was added dropwise with stirring a solution of dithioacetal monoxide 10a $(64.0 \mathrm{mg}, 0.2 \mathrm{mmol})$ in THF. The reaction mixture was stirred for $30 \mathrm{~min}$. The reaction was quenched by sat. aq. $\mathrm{NH}_{4} \mathrm{Cl}$ and the whole was extracted with $n$-hexane. The solution was dried over anhydrous $\mathrm{MgSO}_{4}$ and the solvent was evaporated. The product was purified by silica gel column chromatography to give 19a $(25.1 \mathrm{mg}, 65 \%)$ as colorless oil. IR (neat) 2929 , $2852,1478,1438,1262,1025,750,691 \mathrm{~cm}^{-1}$; ${ }^{1} \mathrm{H}-\mathrm{NMR} \delta 1.21-1.41(5 \mathrm{H}$, m), $1.59-1.63(1 \mathrm{H}, \mathrm{m}), 1.75-1.79(2 \mathrm{H}, \mathrm{m}), 1.97-2.00(2 \mathrm{H}, \mathrm{m}), 3.07-$ $3.13(1 \mathrm{H}, \mathrm{m}), 7.19-7.40(5 \mathrm{H}, \mathrm{m})$. MS $m / z(\%) 192\left(\mathrm{M}^{+}, 36\right), 110(100), 83$ (11). Calcd for $\mathrm{C}_{12} \mathrm{H}_{16} \mathrm{~S}: \mathrm{M}, 192.0971$. Found: $m / z$ 192.0967.

p-Chlorophenylthiocyclohexane (19b): Colorless oil. IR (neat) 2931, 2853, 1472, 1095, 1013, $820 \mathrm{~cm}^{-1}$; ${ }^{1} \mathrm{H}-\mathrm{NMR} \delta 1.23-1.39(5 \mathrm{H}, \mathrm{m}), 1.60-$ $1.63(1 \mathrm{H}, \mathrm{m}), 1.76-1.78(2 \mathrm{H}, \mathrm{m}), 1.95-1.97(2 \mathrm{H}, \mathrm{m}), 3.03-3.08(1 \mathrm{H}, \mathrm{m})$, $7.23-7.33(4 \mathrm{H}, \mathrm{m})$. MS $m / z(\%) 226\left(\mathrm{M}^{+}, 31\right), 144(100), 108(15), 83$ (22). Calcd for $\mathrm{C}_{12} \mathrm{H}_{15} \mathrm{ClS}: \mathrm{M}, 226.0581$. Found: $\mathrm{m} / \mathrm{z} 225.0580$.

p-Fluorophenylthiocyclohexane (19c): Colorless oil. IR (neat) 2931, 2853, 1589, 1490, 1448, 1227, 1155, $831 \mathrm{~cm}^{-1} ;{ }^{1} \mathrm{H}-\mathrm{NMR} \delta 1.19-1.37(5 \mathrm{H}$, $\mathrm{m}), 1.58-1.62(1 \mathrm{H}, \mathrm{m}), 1.75-1.77(2 \mathrm{H}, \mathrm{m}), 1.92-1.95(2 \mathrm{H}, \mathrm{m}), 2.94-$ $3.00(1 \mathrm{H}, \mathrm{m}), 6.96-7.02(2 \mathrm{H}, \mathrm{m}), 7.38-7.46(2 \mathrm{H}, \mathrm{m}) . \mathrm{MS} m / z(\%) 210$ $\left(\mathrm{M}^{+}, 35\right), 128$ (100), 83 (25). Calcd for $\mathrm{C}_{12} \mathrm{H}_{15} \mathrm{FS}: \mathrm{M}, 210.0878$. Found: $m / z$ 210.0879 .

Ethyl 2-(p-Chlorophenylthio)-4-phenylbutanoate (20) To a solution of $t$ - BuMgCl $(0.1 \mathrm{ml}, 0.1 \mathrm{mmol})$ in $2 \mathrm{ml}$ of THF at $-78^{\circ} \mathrm{C}$ was added dropwise with stirring a solution of dithioacetal monoxide $\mathbf{8 b}(84.2 \mathrm{mg}$, $0.2 \mathrm{mmol}$ ) in THF. After $5 \mathrm{~min}$, to the reaction mixture was added dropwise $i-\mathrm{PrMgCl}(0.3 \mathrm{ml}, 0.6 \mathrm{mmol})$ and the reaction mixture was warmed to room temperature. After $10 \mathrm{~min}$, ethyl chloroformate $(0.10 \mathrm{ml}, 1.00 \mathrm{mmol})$ was added to the flask. The reaction mixture was stirred for $60 \mathrm{~min}$. The reaction was quenched by sat. aq. $\mathrm{NH}_{4} \mathrm{Cl}$ and the whole was extracted with $n$-hexane and AcOEt. The solution was dried over anhydrous $\mathrm{MgSO}_{4}$ and the solvent was evaporated. The product was purified by silica gel column chromatography to give 20 (34.0 mg, 51\%) as colorless oil. IR (neat) 2929, 1732 (CO), $1476,1259,1095,746,700 \mathrm{~cm}^{-1}$; ${ }^{1} \mathrm{H}-\mathrm{NMR} \delta 1.20(1 \mathrm{H}, \mathrm{t}, J=7.2 \mathrm{~Hz})$, $1.99-2.08(1 \mathrm{H}, \mathrm{m}), 2.15-2.25(1 \mathrm{H}, \mathrm{m}), 2.75(2 \mathrm{H}, \mathrm{t}, J=7.6 \mathrm{~Hz}), 3.57(1 \mathrm{H}$, $\mathrm{t}, J=7.4 \mathrm{~Hz}), 4.08-4.16(2 \mathrm{H}, \mathrm{m}), 7.15-7.37(9 \mathrm{H}, \mathrm{m}) . \mathrm{MS} \mathrm{m} / \mathrm{z}(\%) 334$ $\left(\mathrm{M}^{+}, 57\right), 230$ (20), 191 (19), 157 (27), 144 (16), 117 (65), 91 (100). Calcd for $\mathrm{C}_{18} \mathrm{H}_{19} \mathrm{ClO}_{2} \mathrm{~S}: \mathrm{M}, 334.0792$. Found: $m / z 334.0790$.

Ethyl 4-Phenylbutanoate (21) To a solution of $20(63 \mathrm{mg}, 0.19 \mathrm{mmol})$ in benzene $(5 \mathrm{ml})$ at room temperature were added $\mathrm{Bu}_{3} \mathrm{SnH}(0.22 \mathrm{ml}$, $0.8 \mathrm{mmol})$ and AIBN $(33.9 \mathrm{mg}, 0.2 \mathrm{mmol})$ with stirring. The reaction mixture was refluxed for $4 \mathrm{~h}$ and then the whole was extracted with $n$-hexane and AcOEt. The organic solution was washed with water, then dried over anhydrous $\mathrm{MgSO}_{4}$. The solvent was evaporated and the residue was purified by silica gel column chromatography to give $21(33.3 \mathrm{~g}, 92 \%)$ as colorless oil. IR (neat) 2935, 1735 (CO), 1201, 1031, 745, $700 \mathrm{~cm}^{-1}$; ${ }^{1} \mathrm{H}-\mathrm{NMR} \delta 1.25$ $(3 \mathrm{H}, \mathrm{t}, J=7.2 \mathrm{~Hz}), 1.96(2 \mathrm{H}$, quin, $J=7.6 \mathrm{~Hz}), 2.32(2 \mathrm{H}, \mathrm{t}, J=7.5 \mathrm{~Hz}), 2.65$ $(2 \mathrm{H}, \mathrm{t}, J=7.6 \mathrm{~Hz}), 4.12(2 \mathrm{H}, \mathrm{q}, J=7.1 \mathrm{~Hz}), 7.17-7.20(3 \mathrm{H}, \mathrm{m}), 7.26-7.30$ (2H, m). MS $m / z(\%) 192\left(\mathrm{M}^{+}, 32\right), 147$ (40), 104 (57), 91 (60), 84 (72), 49 (100). Calcd for $\mathrm{C}_{12} \mathrm{H}_{16} \mathrm{O}_{2}$ : M, 192.1148. Found: $m / z$ 192.1142.

Ethyl (E)-4-Phenyl-2-butenoate (22) To a solution of $20(80 \mathrm{mg}$, $0.24 \mathrm{mmol})$ in $\mathrm{CH}_{2} \mathrm{Cl}_{2}(2.4 \mathrm{ml})$ at $-40{ }^{\circ} \mathrm{C}$ was added MCPBA $(65.1 \mathrm{mg}$, $0.26 \mathrm{mmol}$ ) with stirring. The reaction mixture was stirred for $2 \mathrm{~h}$. The reaction was quenched by sat. aq. $\mathrm{Na}_{2} \mathrm{SO}_{3}$ and the whole was extracted with $n$ hexane and AcOEt. The organic solution was washed with water and dried over anhydrous $\mathrm{MgSO}_{4}$. The solvent was evaporated and the residue was purified by silica gel column chromatography to give ethyl 2 -( $p$-chlorophenylsufinyl)-4-phenylbutanoate (diasteromeric mixture; colorless oil. IR (neat) 2981, 1730 (CO), 1475, 1148, 1091, 1057 (SO), 1012, 825, 742, $701 \mathrm{~cm}^{-1}$; ${ }^{1} \mathrm{H}-\mathrm{NMR} \delta 1.12-1.18(3 \mathrm{H}, \mathrm{m}), 2.08-2.21(1 \mathrm{H}, \mathrm{m}), 2.30-2.44(1 \mathrm{H}, \mathrm{m})$, $2.62-2.67(1 \mathrm{H}, \mathrm{m}), 2.74-2.82(1 \mathrm{H}, \mathrm{m}), 3.42(0.5 \mathrm{H}, \mathrm{dd}, J=10.4,4.0 \mathrm{~Hz})$, $3.58(0.5 \mathrm{H}, \mathrm{dd}, J=10.1,4.6 \mathrm{~Hz}), 3.95-4.13(2 \mathrm{H}, \mathrm{m}), 7.10-7.29(5 \mathrm{H}, \mathrm{m})$, $7.46-7.55$ (4H, m). MS $m / z(\%) 350\left(\mathrm{M}^{+}\right.$, trace), 191 (82), 190 (33), 160 (25), 145 (54), 117 (80), 91 (100). Calcd for $\mathrm{C}_{18} \mathrm{H}_{19} \mathrm{ClO}_{3} \mathrm{~S}: \mathrm{M}, 350.0744$. Found: $\mathrm{m} / \mathrm{z} 350.0749$ ). The sulfoxide was refluxed for $3.5 \mathrm{~h}$ in toluene and then the whole was extracted with $n$-hexane and AcOEt. The organic solution was washed with water, then dried over anhydrous $\mathrm{MgSO}_{4}$. The solvent was evaporated and the residue was purified by silica gel column chromatog- 
raphy to give 22 ( $32.0 \mathrm{~g}, 84 \%, 2$ steps) as colorless oil. IR (neat) 2982,1720 $(\mathrm{CO}), 1653(\mathrm{C}=\mathrm{C}), 1271,1161,699 \mathrm{~cm}^{-1} ;{ }^{1} \mathrm{H}-\mathrm{NMR} \delta 1.27(3 \mathrm{H}, \mathrm{t}, J=7.2$ $\mathrm{Hz}), 3.52(2 \mathrm{H}, \mathrm{dd}, J=6.7,1.4 \mathrm{~Hz}), 4.18(2 \mathrm{H}, \mathrm{q}, J=7.1 \mathrm{~Hz}), 5.81(1 \mathrm{H}, \mathrm{dt}, J=$ $17.1,1.5 \mathrm{~Hz}), 7.10(1 \mathrm{H}, \mathrm{dt}, J=15.6,6.9 \mathrm{~Hz}), 7.17-7.33(5 \mathrm{H}, \mathrm{m}) . \mathrm{MS} m / z$ (\%) $190\left(\mathrm{M}^{+}, 60\right), 162(8), 145$ (41), 117 (100), 91 (31), 28 (51). Calcd for $\mathrm{C}_{12} \mathrm{H}_{14} \mathrm{O}_{2}: \mathrm{M}, 190.0993$. Found: $m / z 190.0989$.

2-(p-Chlorophenylthio)-4-phenylbutane (23) To a solution of $t$ $\mathrm{BuMgCl}(0.1 \mathrm{ml}, 0.1 \mathrm{mmol})$ in $2 \mathrm{ml}$ of THF at $-78^{\circ} \mathrm{C}$ was added dropwise with stirring a solution of dithioacetal monoxide $8 \mathbf{b}(84.2 \mathrm{mg}, 0.2 \mathrm{mmol})$ in THF. After $5 \mathrm{~min}$, to the reaction solution was added dropwise $i$-PrMgCl $(0.3 \mathrm{ml}, 0.6 \mathrm{mmol})$ and the reaction mixture was warmed to room temperature. After $10 \mathrm{~min}, \mathrm{CuI}(3.8 \mathrm{mg}, 10 \mathrm{~mol} \%)^{25}$ and $\mathrm{CH}_{3} \mathrm{I}(0.06 \mathrm{ml}, 0.88 \mathrm{mmol})$ were added to the flask. The reaction mixture was stirred for $60 \mathrm{~min}$. The reaction was quenched by sat. aq. $\mathrm{NH}_{4} \mathrm{Cl}$ and the whole was extracted with $n$ hexane. The solution was dried over anhydrous $\mathrm{MgSO}_{4}$ and the solvent was evaporated. The product was a mixture of $\mathbf{2 3}(28.4 \mathrm{mg}, 51 \%)$ and 12a (13.1 mg, 25\%). IR (neat) 2925, 1475, 1095, 1013, 819, 746, $699 \mathrm{~cm}^{-1} ;{ }^{1} \mathrm{H}-$ NMR $\delta 1.30(3 \mathrm{H}, \mathrm{d}, J=6.7 \mathrm{~Hz}), 1.77-1.85(1 \mathrm{H}, \mathrm{m}), 1.87-1.94(1 \mathrm{H}, \mathrm{m})$, $2.72-2.83(2 \mathrm{H}, \mathrm{m}), 3.15(1 \mathrm{H}$, sex, $J=6.7 \mathrm{~Hz}), 7.1-7.3(9 \mathrm{H}, \mathrm{m}) .{ }^{13} \mathrm{C}-\mathrm{NMR}$ $\delta 21.05(1 \mathrm{C}, \mathrm{q}), 33.10(1 \mathrm{C}, \mathrm{t}), 38.08(1 \mathrm{C}, \mathrm{t}), 42.74(1 \mathrm{C}, \mathrm{t}), 125.97(1 \mathrm{C}, \mathrm{d})$, 128.43 (4C, d), 128.93 (2C, d), 132.82 (1C, d), 133.29 (2C, d), 133.58 (1C, s), $141.45(1 \mathrm{C}, \mathrm{s})$. MS $m / z(\%) 276\left(\mathrm{M}^{+}, 34\right), 262$ (10), 144 (16), 132 (33), 117 (24), 91 (100). Calcd for $\mathrm{C}_{16} \mathrm{H}_{17} \mathrm{ClS}$ : M, 276.0739. Found: $\mathrm{m} / \mathrm{z}$ 276.0741

3-( $p$-Chlorophenylthio)-1,5-diphenylpentane (24): Colorless oil. IR (neat) 2926, 1496, 1475, 1454, 1095, 1013, 820, 746, $699 \mathrm{~cm}^{-1} ;{ }^{1} \mathrm{H}-\mathrm{NMR} \delta$ $1.83-1.97(4 \mathrm{H}, \mathrm{m}), 2.77(4 \mathrm{H}, \mathrm{t}, J=7.0 \mathrm{~Hz}), 3.01(1 \mathrm{H}$, quin, $J=6.5 \mathrm{~Hz})$, 7.04-7.33 (14H, m). MS m/z (\%) $366\left(\mathrm{M}^{+}, 47\right), 145$ (20), 131 (46), 117 (14), 91 (100). Calcd for $\mathrm{C}_{23} \mathrm{H}_{23}$ ClS: M, 366.1207. Found: $\mathrm{m} / z$ 366.1200.

2-( $p$-Chlorophenylthio)-1,4-diphenylbutane (25): Colorless oil. IR (neat) $3026,2925,1496,1475,1454,1095,1013,745,699 \mathrm{~cm}^{-1} ;{ }^{1} \mathrm{H}-\mathrm{NMR} \delta$ $1.75-1.82(1 \mathrm{H}, \mathrm{m}), 1.90-1.97(1 \mathrm{H}, \mathrm{m}), 2.71-2.77(1 \mathrm{H}, \mathrm{m}), 2.80-2.97$ $(3 \mathrm{H}, \mathrm{m}), 3.24-3.29(1 \mathrm{H}, \mathrm{m}), 7.07-7.31(14 \mathrm{H}, \mathrm{m}) . \mathrm{MS} m / z(\%) 352\left(\mathrm{M}^{+}\right.$, 32), 262 (3), 149 (11), 131 (20), 117 (92), 91 (100). Calcd for $\mathrm{C}_{22} \mathrm{H}_{21} \mathrm{ClS}$ : M, 352.1052. Found: $m / z 352.1061$

2-( $p$-Chlorophenylthio)-1-( $p$-methoxyphenyl)-4-phenylbutane (26): Colorless oil. IR (neat) $2919,1509,1475,1245,1094 \mathrm{~cm}^{-1} ;{ }^{1} \mathrm{H}-\mathrm{NMR} \delta 1.72$ $1.82(1 \mathrm{H}, \mathrm{m}), 1.88-1.97(1 \mathrm{H}, \mathrm{m}), 2.70-2.91(1 \mathrm{H}, \mathrm{m}), 3.20-3.26(1 \mathrm{H}, \mathrm{m})$, $3.78(3 \mathrm{H}, \mathrm{s}), 6.77-6.82(2 \mathrm{H}, \mathrm{m}), 7.01-7.05(2 \mathrm{H}, \mathrm{m}), 7.07-7.10(2 \mathrm{H}, \mathrm{m})$, 7.16-7.27 (7H, m). MS m/z (\%) $382\left(\mathrm{M}^{+}, 47\right), 149$ (15), 131 (32), 121 (83), 117 (100), 91 (93). Calcd for $\mathrm{C}_{23} \mathrm{H}_{23} \mathrm{ClOS}$ : $\mathrm{M}, 382.1156$. Found: $m / z$ 382.1148 .

2-(p-Chlorophenylthio)-1,4-diphenyl-1-butanol (27): Diastereomeric mixture; colorless oil. IR (neat) $3445(\mathrm{OH}), 3027,2926,1475,1095,1013,746$, $699 \mathrm{~cm}^{-1} ;{ }^{1} \mathrm{H}-\mathrm{NMR}$ (more polar product) $\delta 1.60-1.67(1 \mathrm{H}, \mathrm{m}), 1.76-1.83$ $(1 \mathrm{H}, \mathrm{m}), 2.66(1 \mathrm{H}, \mathrm{dt}, J=13.8,8.2 \mathrm{~Hz}), 2.89-2.94(1 \mathrm{H}, \mathrm{m}), 3.11-3.15$ $(1 \mathrm{H}, \mathrm{m}), 3.17(1 \mathrm{H}, \mathrm{d}, J=2.5 \mathrm{~Hz}), 4.51(1 \mathrm{H}, \mathrm{dd}, J=7.9,2.5 \mathrm{~Hz}), 6.97(2 \mathrm{H}, \mathrm{d}$, $J=7.0 \mathrm{~Hz}), 7.14-7.35(12 \mathrm{H}, \mathrm{m}),{ }^{1} \mathrm{H}-\mathrm{NMR}$ (less polar product) $\delta 1.70-$ $1.78(1 \mathrm{H}, \mathrm{m}), 1.92-1.99(1 \mathrm{H}, \mathrm{m}), 2.61(1 \mathrm{H}, \mathrm{dt}, J=13.8,8.4 \mathrm{~Hz}), 2.66(1 \mathrm{H}$, d, $J=2.8 \mathrm{~Hz}), 2.86-2.92(1 \mathrm{H}, \mathrm{m}), 3.27(1 \mathrm{H}, \mathrm{dt}, J=10.1,3.4 \mathrm{~Hz}), 4.76(1 \mathrm{H}$, s), 6.99-7.01 (2H, m), 7.14-7.32 (12H, m). MS $m / z(\%) 368\left(\mathrm{M}^{+}, 6\right), 262$ (74), 117 (98), 91 (100). Calcd for $\mathrm{C}_{22} \mathrm{H}_{21}$ ClOS: M, 368.1002. Found: $m / z$ 368.1009 .

4-(p-Chlorophenylthio)-2,2-dimethyl-6-phenyl-3-hexanol (28): Diastereomeric mixture; colorless oil. IR (neat) $3480(\mathrm{OH}), 2956,1475,1096,1013$, $821,746,700 \mathrm{~cm}^{-1}$; ${ }^{1} \mathrm{H}-\mathrm{NMR}$ (less polar product) $\delta 0.78(9 \mathrm{H}, \mathrm{s}), 1.76$ $1.84(1 \mathrm{H}, \mathrm{m}), 2.03(1 \mathrm{H}, \mathrm{d}, J=4.6 \mathrm{~Hz}), 2.16-2.23(1 \mathrm{H}, \mathrm{m}), 2.79(1 \mathrm{H}, \mathrm{dt}$, $J=13.75,8.5 \mathrm{~Hz}), 3.01-3.06(1 \mathrm{H}, \mathrm{m}), 3.23(1 \mathrm{H}, \mathrm{dt}, J=10.6,2.5 \mathrm{~Hz}), 3.37$ $(1 \mathrm{H}, \mathrm{d}, J=2.4 \mathrm{~Hz}), 7.26-7.31(9 \mathrm{H}, \mathrm{m}) . \mathrm{MS} m / z(\%) 348\left(\mathrm{M}^{+}, 25\right), 262(71)$ 144 (24), 118 (67), 117 (57), 91 (100). Calcd for $\mathrm{C}_{20} \mathrm{H}_{25}$ ClOS: M, 348.1314. Found: $m / z 348.1316$.

2-(p-Chlorophenylthio)-1,4-diphenyl-1-butanone (29): Colorless oil. IR (neat) 2925, $1682(\mathrm{CO}), 1475,1448,1095,1014,746,699 \mathrm{~cm}^{-1} ;{ }^{1} \mathrm{H}-\mathrm{NMR} \delta$ $2.07-2.15(1 \mathrm{H}, \mathrm{m}), 2.29-2.36(1 \mathrm{H}, \mathrm{m}), 2.71-2.84(2 \mathrm{H}, \mathrm{m}), 4.37(1 \mathrm{H}, \mathrm{t}$,
$J=7.2 \mathrm{~Hz}), 7.13-7.29(9 \mathrm{H}, \mathrm{m}), 7.40-7.46(2 \mathrm{H}, \mathrm{m}), 7.54-7.57(1 \mathrm{H}, \mathrm{m})$, 7.82-7.84 (2H, m). MS $m / z(\%) 366\left(\mathrm{M}^{+}, 4\right), 262$ (42), 117 (91), 105 (71), 91 (100), 77 (39). Calcd for $\mathrm{C}_{22} \mathrm{H}_{19} \mathrm{ClOS}: \mathrm{M}, 366.0844$. Found: $\mathrm{m} / \mathrm{z}$ 366.0843 .

$N$-Phenyl-3-( $p$-chlorophenylthio)-4-phenylbutanamide (30): Colorless oil. IR (neat) $3274(\mathrm{NH}), 2923,1659(\mathrm{CO}), 1532,1096,752 \mathrm{~cm}^{-1},{ }^{1} \mathrm{H}-\mathrm{NMR} \delta$ $2.09-2.16(1 \mathrm{H}, \mathrm{m}), 2.36-2.43(1 \mathrm{H}, \mathrm{m}), 2.83-2.94(2 \mathrm{H}, \mathrm{m}), 3.68(1 \mathrm{H}, \mathrm{t}$, $J=7.2 \mathrm{~Hz}), 7.04-7.56(14 \mathrm{H}, \mathrm{m}), 8.21(1 \mathrm{H}, \mathrm{s}) . \mathrm{MS} m / z(\%) 381\left(\mathrm{M}^{+}, 23\right)$, 277 (99), 158 (42), 117 (41), 91 (100). Calcd for $\mathrm{C}_{22} \mathrm{H}_{20}$ ClNOS: M, 381.0955. Found: $m / z$ 381.0963

Acknowledgments We thank Mr. Shinya Kikuchi for his technical assistance. This work was supported by a Grant-in-Aid for Scientific Research No. 11640545 from the Ministry of Education, Culture, Sports, Science and Technology, Japan, which is gratefully acknowledged.

\section{References and Notes}

1) Block E., "Reactions of Organosulfur Compounds," Academic Press, New York, 1978, p. 47.

2) Corey E. J., Seebach D. J., J. Org. Chem., 31, 4097-4099 (1966).

3) Gilman H., Webb F. J., J. Am. Chem. Soc., 62, 987-988 (1940).

4) Gilman H., Webb F. J., J. Am. Chem. Soc., 71, 4062-4066 (1949).

5) Peterson D. J., J. Org. Chem., 32, 1717-1720 (1967).

6) Wakefield B. J., "Organomagnesium Methods in Organic Synthesis," Academic Press, London, 1995.

7) Richey H. G., Jr., "Grignard Reagents New Developments," John Wiley, Chichesterr, 2000.

8) Generation of 1-(methylthio)ethenylmagnesium chlorides ( $\alpha$-thioalkenylmagnesium chloride) from the corresponding ketenedithioacetal monoxides by ethylmagnesium chloride was known: Ogura K., Arai K., Tsuchihashi G., Bull. Chem. Soc. Jpn., 55, 3669-3670 (1982).

9) Generation of the carbanion having oxygen $(4: Y=O)$ : Satoh $T$., Horiguchi K., Tetrahedron Lett., 36, 8235-8238 (1995).

10) Satoh T., Kobayashi S., Nakanishi S., Horiguchi K., Irisa S., Tetrahedron, 55, 2515-2528 (1999).

11) Generation of the carbanion having nitrogen $(4: \mathrm{Y}=\mathrm{N})$ : Satoh $\mathrm{T}$, Ozawa M., Takano K., Kudo M., Tetrahedron Lett., 39, 2345-2348 (1998).

12) Satoh T., Ozawa M., Takano K., Chyouma T., Okawa A., Tetrahedron, 56, 4415-4425 (2000).

13) Satoh T., Matsue R., Fujii T., Morikawa S., Tetrahedron Lett., 41, 6495-6499 (2000)

14) Satoh T., Matsue R., Fujii T., Morikawa S., Tetrahedron, 57, 3891$3898(2001)$

15) Generation of the carbanion having a halogen (4: $X=$ halogen): Satoh T., Takano K., Tetrahedron, 52, 2349-2358 (1996).

16) Satoh T., Takano K., Ota H., Someya H., Matsuda K., Koyama M., Tetrahedron, 54, 5557-5574 (1998).

17) Satoh T., Kurihara T., Fujita K., Tetrahedron, 57, 5369—5375 (2001).

18) Satoh T., Sakamoto T., Watanabe M., Tetrahedron Lett., 43, 2043 2046 (2001)

19) A review for the chemistry of the sulfoxide-metal exchange reaction: Satoh T., J. Syn. Org. Chem. Jpn., 54, 481-489 (1996).

20) Gutierrez C. G., Stringham R. A., Nitasaka T., Glasscock K. G., J. Org. Chem., 45, 3393-3395 (1980).

21) Gutierrez C. G., Summerhays L. R., J. Org. Chem., 49, 5206-5213 (1984).

22) Watanabe Y., Araki T., Ueno Y., Endo T., Tetrahedron Lett., 72, 5385-5388 (1986)

23) Satoh T., Kubota K., Tetrahedron Lett., 41, 2121-2124 (2000).

24) Satoh T., Sugiyama S., Ota H., Tetrahedron Lett., 43, 3033-3036 (2002).

25) Wakefield B. J., "Organomagnesium Methods in Organic Synthesis," Academic Press, London, 1995, pp. 153-154. 